Practical Optics

By B. K. Johnson. Pp. viii+190. (London: The Hatton Press, Ltd., 1945.) 15s. net.

$\mathrm{T}$ HE publishers state that this book is intended to fill a gap existing among the books available for students and industrial physicists. In general, the subject-matter concerns the elements of optical instruments. Of the six chapters, the first three, entitled "Reflection and Refraction", "Focal Length Measurements" and "The Telescope", are mainly devoted to descriptions of experiments, illustrating simple instruments and measurements, to be carried out with spectacle lenses and small prisms. In all work of this kind an optical bench is needed, and the author recommends a steel metre rule set on its edge. In the chapters on "The Microscope" and "Photographic Lenses" less use is made of this method; in the latter, a historical account of the early development of photographic objectives is offered, with suggestions of methods for detecting defects in them, and in the former, magnification, resolution, numerical aperture and illumination are among the subjects considered. The final chapter, on "Optical Glass : its Working and Testing", contains a very short account of glass working, the measurement of refractive indices, curvature, and miscellaneous prism angles, and other workshop operations. The book contains several articles likely to be of interest to teachers of physics; but for the industrial physicist it will be found much less useful than the "Dictionary of Applied Physics", which points out the precautions needed to obtain accurate results. A few developments which have taken place since the "Dictionary" appeared are included in the present volume; but the treatment of them is much too brief to be of practical value. The author does not appear to be familiar with present-day practice and knowledge in some of the subjects he has treated. The mathematics is often badly set out and is not always correct, and a number of other errors have been noted.

The Diagnosis of Mineral Deficiencies in Plants by Visual Symptoms

A Colour Atlas and Guide. By Dr. T. Wallace. Supploment 1944. Pp. 9+48 (plates 115-209). (London: H.M. Stationery Office, 1944.) 5s. net.

$\mathrm{M}$ $\mathrm{UCH}$ attention has been given during the present century to the effect of mineral deficiencies on plant growth, and more recently it has become apparent that the presence of minute traces of new elements are of equal importance. This colour atlas deals with the visual diagnosis of deficiencies of those minerals which have long been known to be essential for plant growth; with the addition of a few trace elements such as boron, manganese and molybdenum, the importance of which has been discovered in more recent years. It forms a supplement to the original work on "Mineral Deficiencies in Plants", published in 1943.

The ninety-four colour plates are, in the main, of good quality and contain information regarding a number of additional crops including flax, broadbean, pea and red clover, lucerne, lettuce, radish, leek, celery, pear, plum and sweet cherry, and further deficiencies are illustrated for other crops already included in the main edition. The effect of nitrogen deficiency is shown for a number of crops, including wheat, flax, vegetable and fruit crops.

Very little is known yet concerning the function of the long-recognized essential elements which are required for plant growth. The discovery of a large number of trace elements which are necessary for normal growth of many species of higher plants and of fungi has raised new problems in plant nutrition, and in view of the continued need for a high level of production of home-produced foodstuffs it is essential that attention should be given to every factor that may reduce crop yield.

This Supplement and the original volume published in 1943 will serve to direct the attention of agriculturists and horticulturists to this important subject.

\section{Annuaire astronomique et météorologique Camille Flammarion pour 1945}

(81e année.) Pp. 382. (Paris : Ernest Flammarion, 1945.) 80 francs.

$T$ HIS volume opens with a short account of the life and work of Camille Flammarion (1842-1925), the founder of the Annuaire, and also contains a preface written by him. This 8 Ist edition has been produced under many difficulties, among which are the restrictions on publications and the partial destruction of the printing establishment by bombardment, and the editor is to be congratulated on his perseverance in surmounting these obstacles. A short description of calendars of different races is followed by "Les Calendriers" for 1945, in which the festivals for various dates are given in three columns under the headings of Christian, Jewish and Mahommedan. G. Flammarion supplies a scheme of a perpetual calendar for every year in accordance with certain suggestions made in comparatively recent times regarding a reformed calendar. The coordinates of the sun and moon in right asconsion and declination to the nearest minute of $\operatorname{tim} \theta$ and minute of are respectively are supplied, together with the times of rising and setting at Paris, the sidereal time, and times of passage of the meridian of Paris. The usual planetary details are included and proper motions of stars, stellar spectra, double stars, variables, etc., are dealt with. Fourteen pages are devoted to problems connected with the physics of the earth, terrestrial magnetism, solar activity, magnetic storms, and also with climatology, including barometric pressure, temperature and rainfall. An index adds very much to the value of this publication. M. D.

\section{Experimental Electronics}

By Prof. Ralph H. Müller, Assist. Prof. R. L. Garman and Assist. Prof. M. E. Droz. (Prentice-Hall Chemistry Series.) Pp. xv+330. (New York: PrenticeHall, Inc. ; London : George Allen and Unwin, Ltd., 1943.) 21s. net.

$\mathrm{O}$ the many text-books introducing the subject of electronics, the one in hand, written by three chemists, approaches the matter entirely from the experimental angle. The extensive demand for this text indicates the success of this point of view; no student can, however, afford to neglect the more rigorous theoretical treatments in this field. In brief, the student is taken through many experiments on simple valves, photo-electric cells, and various multigrid and gaseous tubes. Practical applications include D.c. and A.c. voltmeters, photo-tubes, and various types of amplifier and oscillator. Many references are given at the end of each chapter, together with relevant problems, the more interesting of which include applications to practical problems not discussed in the text.
L. E. C. Hughes. 